\title{
Pengembangan Instrumen Penilaian Rasa Percaya Diri Guru Dalam Upaya Meningkatkan Kinerja Guru Pendidikan Agama Buddha
}

\author{
Doni Wahyudin ${ }^{1}$, Hesti Sadtyadi ${ }^{2}$, Sukarti $^{3}$ \\ Sekolah Tinggi Agama Buddha Negeri Reden Wijaya \\ Wonogiri Jawa Tengah \\ donyghomezt@gmail.com
}

\begin{abstract}
ABSTRAK
Penelitian ini merupakan penelitian pengembangan yang meliputi pengembangan instrumen percaya diri guru pendidikan agama Buddha, dan melakukan modifikasi penilaian kinerja guru pendidikan agama Buddha. Subjek penelitian guru pendidikan agama Buddha. Penelitian dilakukan pada bulan Februari sampai dengan Juni 2019, yang dibagi dalam lima prosedur. Analisis data kualitatif dilakukan untuk mengolah data kualitatif, juga dilakukan analisis dengan Exploratory Factor Analysis. Hasil penelitian menunjukan bahwa faktor yang mempengaruhi percaya diri guru pendidikan agama Buddha adalah faktor lingkungan, suasana kelas dan faktor lingkungan dari tugas tambahan yang dimiliki guru tersebut. Indikator yang mempengaruhi lingkungan kelas, terdiri dari suasana kelas yaitu indikator sarana pendukung belajar, seperti ruang kelas, buku, jumlah siswa, lokasi dan jumlah kelas. Sedangkan faktor lingkungan yang kedua adalah lokasi tugas tambahan yang sesuai, baik sebagai administrasi atau bidang tugas yang lain, sarana pendukung tugas tambahan, dan tekanan kerja. Besarnya pengaruh percaya diri terhadap kinerja guru pendidikan agama Buddha 0,318, yang menunjukkan bahwa prestasi kerja dapat dipengaruhi secara langsung melalui rasa percaya diri sebesar 0,318 . Jika rasa percaya diri mampu ditingkatkan dalam satu satuan, dengan asumsi variabel lain tetap, maka prestasi kerja dapat ditingkatkan sebesar 0,318
\end{abstract}

Kata Kunci : Percaya Diri, Kinerja Guru.

ABSTRACT

This research is a research development that includes the development of confidence instruments of Buddhist education teachers, and modifies the performance evaluation of Buddhist education teachers. The subject of research is Buddhist education teacher. The study was conducted in February to June 2019, which was divided into five procedures. Qualitative data analysis was performed to process qualitative data, also an analysis was carried out with Exploratory Factor Analysis. The results showed that the factors influencing the confidence of Buddhist education teacherswere environmental factors, class atmosphere and environmental factors of the additional tasks that the teacher had. Indicators that affect the classroom environment, consisting of classroom atmosphere, are indicators of learning support facilities, such as classrooms, books, number of students, location and number of classes. Whereas the second environmental factor is the location of the appropriate additional tasks, either as administration or other fields of work, the means of supporting additional tasks, and work pressure. The magnitude of the effect of confidence on the work performance of Buddhist education teacher is 0.318 , which shows that work performance can be directly affected through self-confidence of 0.318 . If self-confidence can be increased in one unit, assuming the other variables are fixed, then work performance can be increased by 0.318

Keywords : Confidence, Teacher Performance.

\section{PENDAHULUAN}

Pendidikan akan berjalan dengan baik apabila komponen dalam pembelajaran lengkap, dengan kata lain semua pihak yang mengisi sesuai dengan tugas, pokok dan fungsinya. Komponen pendidikan bisa diartikan seperti: pendidik, peserta didik, kurikulum, dan sarana prasarana. Masing-masing komponen diatas memiliki fungsi 
yang berbeda-beda. Pendidikan dinilai bermutu baik apabila seorang pendidik melaksanakan tugasnya secara maksimal.

Tuntutan profesionalisme menyebabkan seorang guru bekerja keras dalam meningkatkan pendidikan secara optimal. Hal ini akan menjadi tugas tuntutan yang besar untuk menjadi seorang guru. Zaman sekarang peserta didik mulai beradaptasi dengan teknologi informasi. Hal menyebabkan potensi guru dituntut secara profesional untuk mengahadapinya. Guru dituntut mahir menggunakan alat-alat digital yang berbasis IT (Information Technology) yang semakin canggih. Kemampuan menguasai IT tersebut menjadi keahlian khusus yang dimiliki oleh seorang guru.

Tuntutan pada era Masyarakat Ekonomi Asean (MEA) hendaknya disikapi dunia pendidikan dengan berbagai terobosan agar pendidikan berjalan dengan dinamis. Keberkaitan dengan penggunaan IT sebagai penunjang pelaksanaan penyelenggaraan pendidikan yang memadai. Hal ini dapat membantu perbaikan dari sistem pendidikan yang awalnya manual menjadi digital, sebagai media untuk mempermudah proses pelaksanaan pebelajaran.

Ditinjau dari masa ke masa, kebutuhan pendidikan tentu memerlukan berbagai inovasi dan perbaikan. Inovasi meliputi inovasi peralatan dan sumber daya manusia, ini akan sangat dibutuhkan untuk memfasilitasi proses pendidikan. Fasilitas berupa peralatan dan sarana prasarana pendidikan harus mendapatkan pelayanan yang memadai. Ketersediaan sarana ini akan membantu menyempurnakan proses serta tujuan yang optimal dalam pendidikan. Kenyataan sekarang menunjukan masih banyak peralatan dan sarana prasarana yang belum lengkap di setiap sekolah.

Proses pembelajaran Pendidikan Agama Buddha di berbagai wilayah Indonesia, khususnya pada wilayah Provinsi Jawa Tengah masih dijumpai banyak kekukarangan, kondisi menunjukan pelayanan pendidikan yang belum sempurna. Berdasarkan hasil observasi dan wawancara dengan guru pendidikan Agama Buddha, Anung Purwati menyatakan bahwa:

"kami selaku guru Pendidikan Agama Buddha dalam kegiatan belajar mengajar kami, masih belum maksimal. Dikarenakan kami tidak mempunyai ruang kelas sendiri, harus gantian dengan kelas yang lain untuk pembelajaran,maka dari itu pembelajaran kami belum efisien dan optimal ".

Berkaitan juga dalam hal penyusunan kurikulum nasional, penyelenggara pendidikan pusat tentu memperhatikan kondisi pendidikan dimasing-masing daerah untuk evaluasi pendidikannya. Hal konkret yang terjadi bahwa model evaluasi yang dilakukan dengan cara memukul rata seluruh daerah, tidak mengadopsi berbagai kepentingan dari faktor daerah tersebut. Model evalusi sebaiknya dapat memberikan kesempatan usulan dari masing-masing daerah karena karakter, tempat, budaya, dan gaya pendidikannya berbeda. Misalkan dapat dicontohkan dalam hal penerapan pembelajaran antara siswa dan guru yang tinggal di perkotaan dengan kegiatan pembelajaran di daerah tertinggal dan jauh dari perkotaan. Hal demikian akan sangat tidak adil apabila proses penyusunan kurikulum dilakukan dan dipukul rata keseluruhannya. 
Dari berbagai masalah yang ada, tentunya menuai dampak kepada pesestra didik dan kepada guru tentunya. Dampak bagi siswa tidak begitu menuai kontra yang besar, karena siswa sebenarnya hanya menyesuaikan pendidikan yang dilaksanakan dari penyelenggara pendidikan. Dampak yang besar justru dirasakan oleh guru yang dalam hal ini kunci dari keberhasilan suatu pendidikan, guru harus benar-benar menggunakan kewajiban dan haknya untuk melakasanakan tugasnya dengan maksimal. Tuntutan tugas yang tinggi akan tetapi secara sarana prasarana dan komponen pendidikan yang tidak memadai menjadi penghalang yang besar bagi seorang guru pendidikan agama Buddha.

Berdasarakan masalah- masalah yang ada, hal yang mendasar peneliti dalam mengkaji adalah bahwa guru pendidikan agama Buddha yang belum bisa menjadi guru yang percaya diri dalam melaksanakan kegiatan belajar mengajar. Pelaksanaan belajar akan optimal apabila sarana prasana serta mental pendidik yang baik. Maka dalam hal ini peneliti tertarik untuk mengkaji lebih dalam terkait bagaimana Pengembangan Instrumen Rasa Percaya Diri dalam Meningkatkan Kinerja Guru pendidikan Agama Buddha sebagai bahan untuk memecahkan permasalahan yang terjadi.

Menurut Ghufron (2014:35) Kepercayaan diri adalah keyakinan untuk melakukan sesuatu pada diri subyek sebagai karakteristik pribadi yang terdapat keyakinan akan kemampuan diri, optimis, bertanggungjawab, rasional, dan realistis. Menurut Willis dalam Ghufron (2014: 34) merupakan keyakinan bahwa seseorang mampu menanggulangi suatu masalah dengan situaasi terbaik dan dapat memberikan sesuatu yang menyenangkan bagi orang lain. Kepercayaa diri akan muncul dalamn setiap insan pribadi manusia. Manusia yang percaya diri tentunya dapat melakukan segala aktivitasnya dengan matang dan mudah untuk beradaptasi di lingkungan yang baru. Proses kepercayaan diri akan tumbuh pada diri manusia pada saat seseorang akan melakukan aktivitas dan akan memberikan yang terbaik.

Menurut Lauster (1992) dalam Ghufron, (2014: 35) orang yang memiliki kepercayaan diri yang positif adalah ia akan memiliki: 1) Keyakinan Kemampuan diri; 2) Optimis; 3) Objektif; 4) Bertanggung Jawab; dan 5) Rasional dan Realistis.

Sistem Pendidikan Nasional menyatakan dalam pasal 39 ayat 2 tentang Pendidik dan tenaga kependidikan bahwa guru atau pendidik merupakan tenaga profesional yang bertugas merencanakan dan melaksanakan proses pembelajaran, menilai hasil pembelajaran, melakukan bimbingan dan pelatihan, serta melakukan penelitian dan pengabdian kepada masyarakat, terutama bagi pendidik pada perguruan tinggi. Dalam Kamus Besar Bahasa Indonesia (KBBI) Guru diartikan sebagai orang yang pekerjaannya mengajar. Guru adalah salah satu komponen manusiawi dalam proses belajar mengajar, yang ikut berperan serta dalam usaha pembentukan sumber daya manusia yang potensial di bidang pembangunan.

Dalam pendapat ahli (Casio, 1998: 43) dan Bates dan Holton dalam (Jones, et, al, 2006: 3), kinerja dipengaruhi oleh banyak variabel yang bersifat multi dimensional. Variabel yang berkaitan dengan kinerja juga sangat bervariasi. Berkaitan dengan jenis pekerjaan, maka kinerja juga memperhitungkan banyak aspek, seperti 
aspek output dan pencapaian tujuan, kinerja juga dikaitkan dengan interaksi antara berbagai faktor yang membentuknya. Lebih spesifik disampaikan Evan \& Lindsay (2002: 297), yang menyatakan bahwa adanya keberagaman kinerja, tetapi indikator capaiannya hampir sama, baik terkait dengan prestasi kerja yang seiring dengan kemampuan maupun motivasi.

Berkaitan dengan penilaian kinerja dengan pendapat-pendapat ahli, yang tidak sedikit, dengan pemahaman yang hampir sama antara satu dengan yang lain. Rivai, et al. (2008: 5), membedakan dua kelompok evaluasi kinerja yaitu judgment dan rating behavior. Judgment menunjukkan evaluasi diri (self evaluation) artinya individu menganalisis kinerja sendiri, sedangkan rating scale behaviour menunjukkan penilaian kinerja yang dilakukan orang lain (penilai, penyelia). Sedangkan dalam hal indikator kinerja menurut Mahsum (2006: 5), istilah indikator kinerja mengacu pada penilaian kinerja secara tidak langsung, yaitu hal-hal yang sifatnya hanya merupakan indikasi-indikasi kinerja, sedangkan ukuran kinerja mengacu pada penilaian kinerja secara langsung. Penilaian kinerja berdasarkan penilaian subyektif diri sendiri (self evaluation), dengan kriteria psikososoial, yaitu kepuasan usaha, kemandirian, kebanggaan, dan pelayanan pada masyarakat.

Manajemen berdasarkan sasaran (Management by Objective), adalah satu bentuk penilaian di mana karyawan dan penyelia menetapkan tujuan-tujuan atau sasaran-sasaran pelaksanaan kerja karyawan secara individu di waktu yang akan datang. MBO merupakan proses mengonversi tujuan-tujuan organisasi ke dalam sasaran-sasaran individual, yang merupakan sasaran obyektif yang terukur, dan disepakati secara bersama. Dalam MBO (Rivai, et al., 2008:374) harus memuat sasaran-sasaran seperti: 1)Mengidentifikasi hasil yang ditentukan; 2) Menentukan batas waktu sasaran dapat dicapai; 3) Menentukan biaya sasaran dapat dicapai; 4) Mempunyai ukuran yang jelas; 5) Realistik, menentang, terukur; dan 6) Konsisten terhadap rencana, kebijakan dan prosedur yang berlaku.

Pendekatan penilaian ini dapat digunakan dalam mengatasi masalah kelemahan-kelemahan dari bentuk penilaian kinerja yang lain. Pendekatan ini lebih berorientasi pada pendekatan hasil.

\section{Kerangka Berfikir}

Gambar 1.1

\section{Kerangka Berfikir}

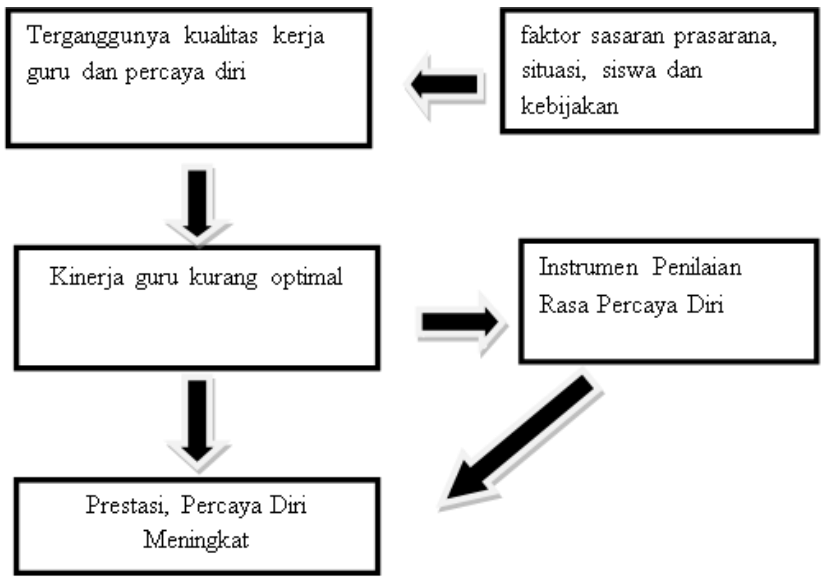

Berdasarkan kerangka berpikir dapat dijelaskan bahwa proses pelaksanaan tugas guru dalam pembelajaran mengalami penurunan dikarenakan ada beberapa faktor yang mempengaruhi seperti sarana prasarana, situasi, siswa dan lain-lain. Hal ini akan mengakibatkan tugas sebagai guru akan menjadi kurang optimal, sehingga peneliti akan mengembangakn dengan 
cara membuat instrumen penilain rasa percaya diri guru untuk meningkatan kinerja guru pendidikan agama Buddha.

\section{METODE PENELITIAN}

Penelitian yang di lakukan menggunakan jenis penelitian pengembangan atau Research and Development $(R \& D)$. Metode penelitian dan Pengembangan $(R \& D)$ adalah metode penelitian yang digunakan untuk menghasilkan rancangan produk baru, menguji keefektifan produk yang telah ada, serta mengembangkan dan menciptakan produk baru. Bila produk baru telah teruji, maka produk tersebut bila digunakan dalam pekerjaan maka pelaksanaan pekerjaan akan lebih mudah, lebih cepat kuantitas dan kualitas produk hasil kkerja akan meningkat (Sugiyono, 2016: 26).

Tahapan-tahapan yang ada tidak meninggalkan sepuluh (10) tahap dari model Borg and Gall, yang jika disederhanakan menjadi: 1) Tahap Pendahuluan; 2) Tahap Perencanaan; 3) Tahap Uji Coba, Evaluasi dan Revisi; serta 4) Tahap Implementasi. Prosedur pengembangan dalam menyusun instrumen, mengacu pada saran yang ditawarkan oleh Borg \& Gall (1983: 774787). Langkah-langkah Pengembangan asesmen kinerja guru sekolah dasar melalui: 1) Penyusunan Desain dan Perangkat Instrumen; 2) Validasi ahli/ sejawat; 3) Uji Coba; 4) Analisis data; dan 5) Implementasi.

Subyek penelitian adalah instrumen penilaian rasa percaya diri guru. Jumlah guru yang dibutuhkan dalam penelitian ini adalah 60 guru PAB. Penentuan ukuran menggunakan rumus yang dikembangkan dari Issac Michael (Sugiyono, 2015: 69). Variabel pada penelitian ini adalah rasa percaya guru dan peningkatan kinerja guru Pendidikan Agama Buddha. Rasa percaya diri guru akan dapat mengoptimalkan suatu kinerja seorang guru dalam melakukan profesinya sesuai dengan faktor serta indikator percaya diri yang telah ditentukan berdasarkan analisis dan kajian teori dan telah melalui validasi isi dan instrumen.

Penelitian dan pengembangan ini menggunakan beberapa macam metode dalam mengumpulkan data, yaitu kuesioner, observasi, dan wawancara. Hasil pengumpulan data survei dan dari FGD dianalisis dengan metode kualitatif. Sedangkan data hasil pengembangan asesmen dianalisis secara kuantitatif. Instrumen pengumpulan data dianalisis dengan EFA (Exploratory Faktor Analysis), (Eisengart, 2006), instrumen akan dilakukan analisis diskriptif berdasarkan penilaian guru, kepala sekolah dan pengawas.

\section{HASIL PENELITIAN}

\section{A.Deskripsi Data Hasil Pengembangan (EFA)}

Data Hasil Studi Awal

Penelitian ini merupakan penelitian pengembangan, yang bertujuan untuk mengembangkan instrumen penilaiaan percaya diri guru. Studi pendahuluan dilakukan melalui tahap studi kepustakaan, yang dilakukan dalam upaya mengetahui teori-teori pendukung yang berkaitan dengan percaya diri dan kinerja guru. hasil studi pendahuluan terdapat dalam bab II yang menyajikan teori berkaitan dengan percaya diri dan kinerja guru.

Tahap selanjutnya adalah melakukan prasurvei dilingkungan Karesidenan Banyumas pada bulan september 2018 dalam pertemuan KKG Dan MGMP Kab Banyumas yang 
bersamaan dengan penelitian Hesti Sadtyadi, dalam pertemuan ini menghasilkan data berkaitan dengan instrumen penilaiaan percaya diri guru, ynag digunkan sebagai penilaian kepercayaan diri dan kinerja guru pendidikn agama Buddha dilingkunan Banyumas.

Tahap Pengembangan Instrumen Penilaian Rasa Percaya Diri

Penelitian ini diawali dengan penyususan indikator percaya diri dan kinerja melalui teoritis dan telaah empirik. Telaah empirik dilakukan dengan menggunakan teknik FGD yang dilakukan analisis secara bertahap. dalam tahap awal setelah tersusunnya draf awal penelitian, maka dilakukan analisis melalui Fokus Group Discution (FGD). FGD ini dilakukan dalam rangka mendapatkan masukan berkaitan dengan draf instrumen yang telah disusun, untuk mendapatkan masukan yang berkaitan baik secara teoritis, konsep, selain diuji keterbacaan.

Dalam penelitian ini analisisn FGD dilakukan secara bertahap. Tahap awal draf disusun, dilakukan sebelum instrumen diujikan, maka telaah oleh bapak ibu dosen dilingkungan STAB Negeri Raden Wijaya Wonogiri Jawa Tengah, Yakni Bapak Hariyanto dalam bidang pendidikan, Bapak Hesti Sadtyadi dalam Bidang evaluasi pendidikan dan Bapak Sujiono dalam bidang kebahasaan. Selain itu dalam telaah awal melibatkan mahasiswa di lingkungan STAB Negeri Raden Wijaya Wonogiri Jawa Tengah untuk melakukan uji keterbacaan, dengan metode respon atau tanggapan dan masukan terhadap instrumen yang disusun, juga terhadap guru pendidikan agama Buddha, dalam melakukan validasi lebih lanjut. Dalam hal ini instrumen yang digunakan peneliti sudah digunakan dalam penelitian Dr Hesti Sadtyadi S.E., M.Si pada penelitian sebelumnya dengan hasil dari proses ini menunjukan bahwa instrumen telah baik untuk digunakan, dengan skor aiken berkisar 0,7 sampai dengan 0,8. Rangkuman teknik hasil FGD I Yang merupakan validasi isi, terlampir di lampiran 2 .

Setelah dilakukan perbaikan dan penyempurnaan terhadap instrumen, dilanjtkan dengan uji coba pendahuluan yang dilakukan Bulan Maret 2019. hap Diskusi kedua setelah dilakukan analisis dengan komponen yang sama dan telaah bersama, menghasilkan beberapa masukan reviu dan evaluasi, yang menghasilkan peningkatan kualitas standar dalam validitas secara kualitatif, dengan metode aiken, menghasilkan penilaian validitas yang sangat baik, telah mencapai 0,8. Setelah uji melalui FGD, dilakukan tindak lanjut dengan melalukan uji skala yang lebih besar. Uji tersebut merupakan uji akhir, sekaligus merupakan bagian dari deseminasi. Deseminasi selanjutnya dilakukan melulai seminar hasil penelitian.

Dalam uji tahap I dengan teknik analisis yang digunkan adalah Exploratory Faktor Analysis (EFA). Uji tahap I ini dilakukan dalam rangka mendapatkan indikator dan faktor penyusun komponen baik kinerja dan percaya diri maupun faktor lain yang berpeluang menyusun komponen-komponen yang berkaitan. Penelitian yang dilakukan di bulan Oktober 2018, dengan subyek penelitian adalah guru pendidikan agama Buddha untuk wilayah Karesidenan Banyumas Total data sebagai responden 20 orang guru, baik sebagai penilai diri maupun sejawat.

Berdasarkan analisis faktor denngan mempergunakan program SPSS versi 25, menunjukan KMO model instrumen sebesar 0,696 
yang ditampiklan pada tabel.1, dengan Chi Square signifikan dibawah 0,05 yang berarti tingkat kesalahan dibawah 0,05, dalam peneilitian ini adalah dengan tingkat kesalahan 0 dan KMO diatas 0,5 , berarti model dapat dipergunakan untuk analisis lebih lanjut.

Tabel.1

Analisis Data EFA dengan KMO

\begin{tabular}{|l|l|r|}
\hline \multicolumn{3}{|c|}{ KMO and Bartlett's Test } \\
\hline \multicolumn{2}{|l|}{ Kaiser-Meyer-Olkin } & .696 \\
Measure of Sampling & \\
Adequacy. & \\
\hline Bartlett' & Approx. Chi- & 2520.85 \\
s Test & Square & 7 \\
of & df & 780 \\
\cline { 2 - 3 } Spherici & Sig. & .000 \\
ty & & \\
\hline
\end{tabular}

Tabel.2

Analisis Anti Image dengan EF

\begin{tabular}{|c|c|c|c|c|}
\hline \multirow{15}{*}{ 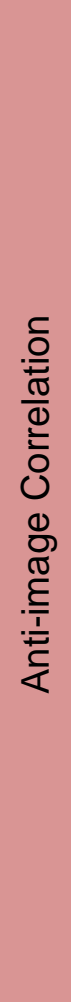 } & Kinerja1 & $.705^{\mathrm{a}}$ & Kinerja21 & $.651^{\mathrm{a}}$ \\
\hline & Kinerja2 & $.803^{\mathrm{a}}$ & Kinerja22 & $.720^{\mathrm{a}}$ \\
\hline & Kinerja3 & $.540^{\mathrm{a}}$ & Kinerja23 & $.660^{\mathrm{a}}$ \\
\hline & Kinerja4 & $.796^{\mathrm{a}}$ & Kinerja24 & $.605^{\mathrm{a}}$ \\
\hline & Kinerja5 & $.840^{\mathrm{a}}$ & Kinerja25 & $.733^{\mathrm{a}}$ \\
\hline & Kinerja6 & $.758^{a}$ & Kinerja26 & $.669^{a}$ \\
\hline & Kinerja7 & $.700^{\mathrm{a}}$ & Kinerja27 & $.751^{\mathrm{a}}$ \\
\hline & kinerja8 & $.734^{a}$ & Kinerja28 & $.684^{\mathrm{a}}$ \\
\hline & Kinerja9 & $.716^{\mathrm{a}}$ & Kinerja29 & $.601^{\mathrm{a}}$ \\
\hline & Kinerja10 & $.756^{\mathrm{a}}$ & Kinerja30 & $.558^{\mathrm{a}}$ \\
\hline & Kinerja11 & $.829^{a}$ & Percydiri1 & $.455^{a}$ \\
\hline & Kinerja12 & $.746^{\mathrm{a}}$ & Percydiri2 & $.586^{\mathrm{a}}$ \\
\hline & Kinerja13 & $.639^{\mathrm{a}}$ & Percydiri3 & $.730^{\mathrm{a}}$ \\
\hline & Kinerja14 & $.677^{\mathrm{a}}$ & Percydiri4 & $.667^{a}$ \\
\hline & Kinerja15 & $.738^{a}$ & Percydiri5 & $.746^{\mathrm{a}}$ \\
\hline
\end{tabular}

\begin{tabular}{|l|l|l|l|l|}
\hline & Kinerja16 & $.632^{\mathrm{a}}$ & Percydiri6 & $.748^{\mathrm{a}}$ \\
\cline { 2 - 5 } Kinerja17 & $.800^{\mathrm{a}}$ & Percydiri7 & $.450^{\mathrm{a}}$ \\
\hline Kinerja18 & $.797^{\mathrm{a}}$ & Percydiri8 & $.661^{\mathrm{a}}$ \\
\hline Kinerja19 & $.637^{\mathrm{a}}$ & Percydiri9 & $.582^{\mathrm{a}}$ \\
\cline { 2 - 5 } Kinerja20 & $.751^{\mathrm{a}}$ & Percydiri10 & $.691^{\mathrm{a}}$ \\
\hline
\end{tabular}

Memperhatikan nilai anti image tiap instrumen yang dianalisis menunjukan bahwa tiap intrumen valid, yang ditunjukan dari nilai anti image diatas 0.3 , yang berarti setiap instrumen valid. Walaupun demikian dalam uji ini, tetap memperhatikan hasil koreksi dari tim reveiu instrumennya, sehingga mampu menjaga validitas dan reliabilitas instrumen penilitan ini. Dalam hal ini pemberian masukan terhadap instrumen dilakukan dengan memberikan masukan secara tertulis melalui lembar form koreksi instrumen dan penilaianya yang dapat dikatakan bahwa intrumennya telah layak untuk digunakan. Hal ini menunjukan bahwa instrumen telah teruji validitasnya, baik secara kontek, isi, juga secara statistik.

\section{Tabel.3}

Analisis Loading Faktor dengan EFA

\begin{tabular}{|c|c|c|c|c|c|c|c|c|c|}
\hline \multicolumn{10}{|c|}{ Rotated Component Matrix ${ }^{a}$} \\
\hline \multicolumn{3}{|c|}{1} & \multirow{2}{*}{$\begin{array}{c} \\
2 \\
0.776 \\
\end{array}$} & \multirow{2}{*}{ Kinerja17 } & \multirow{2}{*}{$\begin{array}{c}\text { Compor } \\
3 \\
0.887 \\
\end{array}$} & \multicolumn{2}{|l|}{ ent } & \multirow{2}{*}{\begin{tabular}{|c|}
5 \\
Kinerja9
\end{tabular}} & \multirow[b]{2}{*}{0.787} \\
\hline Kinerja24 & 0.882 & Kinerja1 & & & & $\frac{4}{\text { Kinerja13 }}$ & 0.878 & & \\
\hline Kinerja25 & 0.847 & Kinerja2 & 0.767 & Kinerja18 & 0.852 & Kinerja14 & 0.781 & $\begin{array}{c}\text { Kinerja1 } \\
0\end{array}$ & 0.605 \\
\hline Kinerja26 & 0.894 & Kinerja3 & 0.810 & Kinerja19 & 0.881 & Kinerja15 & 0.850 & $\begin{array}{c}\text { Kinerja1 } \\
1\end{array}$ & 0.732 \\
\hline Kinerja27 & 0.689 & Kinerja4 & 0.828 & Kinerja20 & 0.880 & Kinerja16 & 0.797 & $\begin{array}{c}\text { Kinerja1 } \\
2\end{array}$ & 0.764 \\
\hline Kinerja28 & 0.760 & $\begin{array}{l}\text { Percydir } \\
\text { i6 }\end{array}$ & 0.819 & & & & & & \\
\hline Kinerja29 & 0.778 & & & & & & & & \\
\hline 6 & & 7 & & 8 & & 9 & & 10 & \\
\hline Kinerja5 & 0.458 & $\underset{1}{\text { Kinerja2 }}$ & 0.898 & $\begin{array}{l}\text { Percydiri } \\
3\end{array}$ & 0.858 & Kinerja30 & 0.869 & $\begin{array}{l}\text { Percydir } \\
\text { i7 }\end{array}$ & 0.770 \\
\hline Kinerja6 & 0.536 & $\begin{array}{c}\text { Kinerja2 } \\
2\end{array}$ & 0.760 & $\begin{array}{c}\text { Percydiri } \\
4\end{array}$ & 0.873 & $\begin{array}{c}\text { Percydiri } \\
1\end{array}$ & 0.825 & $\begin{array}{c}\text { Percydir } \\
\text { i9 }\end{array}$ & 0.775 \\
\hline Percydiri8 & 0.856 & $\begin{array}{l}\text { Kinerja2 } \\
3\end{array}$ & 0.894 & $\begin{array}{l}\text { Percydiri } \\
5\end{array}$ & 0.834 & $\begin{array}{c}\text { Percydiri } \\
2\end{array}$ & 0.922 & & \\
\hline $\begin{array}{c}\text { Percydiri1 } \\
0\end{array}$ & 0.769 & & & & & & & & \\
\hline & & & & & & & & & \\
\hline
\end{tabular}

Berdasarkan loading faktor komponen kinerja menunjukan bahwa komponen kinerja 
dapat disusun dari komponen tugas guru dalam mengajar, membimbing, melatih, mendidik, menilai, dan mengevaluasi yang dalam penelitian ini dirangkum menjadi tiga komponen perencanaan pembelajaran, pelaksanaan pembenlajaran, dan komponen menilai serta mengevaluasi. Tiap komponen tugas guru sebagai komponen kinerja guru masing-masing disusun oleh empat indikator yang dominan, dengan loading faktor lebih besar dari 0,5. Komponen percaya diri, dapat dijelaskan oleh sub komponen Lingkungan suasana kelas, dan lingkunagn tugas tambahan, kedua sub komponen tersebut menyumbang faktor percaya diri. Tiap komponen disusun oleh empat indikator yang dominan, dengan nilai loading faktor lebih besar 0,5 .

Tabel.4

Analisis Regresi linear dengan SPSS

\begin{tabular}{|c|c|c|c|c|c|c|c|c|c|}
\hline \multicolumn{10}{|c|}{ Model Summary ${ }^{b}$} \\
\hline \multirow{2}{*}{$\begin{array}{l}\text { Mo } \\
\text { del }\end{array}$} & \multirow[t]{2}{*}{$\mathrm{R}$} & \multirow{2}{*}{$\begin{array}{c}\text { R } \\
\text { Squa } \\
\text { re }\end{array}$} & \multirow{2}{*}{$\begin{array}{l}\text { Adjusted } \\
\text { R Square }\end{array}$} & \multirow{2}{*}{$\begin{array}{l}\text { Std. } \\
\text { Error of } \\
\text { the } \\
\text { Estimate }\end{array}$} & \multicolumn{5}{|c|}{ Change Statistics } \\
\hline & & & & & $\begin{array}{l}\text { R Square } \\
\text { Change }\end{array}$ & $\begin{array}{c}\text { F } \\
\text { Chang } \\
e \\
\end{array}$ & $\begin{array}{l}d \\
f \\
1 \\
\end{array}$ & $\begin{array}{l}d \\
f \\
2\end{array}$ & $\begin{array}{l}\text { Sig. F } \\
\text { Change }\end{array}$ \\
\hline 1 & $.318^{\mathrm{a}}$ & .101 & .078 & 5.68986 & .101 & 4.286 & 1 & $\begin{array}{l}3 \\
8 \\
\end{array}$ & .045 \\
\hline \multicolumn{10}{|c|}{ a. Predictors: (Constant), kinerjaguru } \\
\hline & ent & ble: & yadiri & & & & & & \\
\hline
\end{tabular}

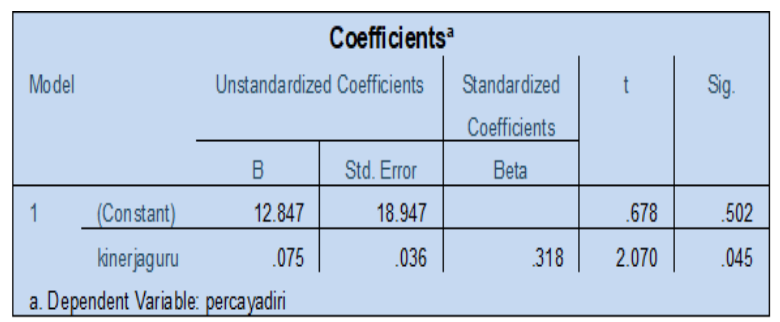

Berdasarkan sajian data yang ditampilkan pada tabel 4, bahwa kinerja pendidikan dapat dipengaruhi oleh rasa percaya diri menunjukan $R$ Square Change sebesar 0,318 hal ini menunjukan bahwa kinerja guru pendidikan agama Buddha dapat dipengaruhi oleh percaya diri dengan nilai 0,318 .

\section{B.Analisis Deskriptif Data Penelitian}

Kontribusi tekanan kerja, yang dapat dijelaskan dalam penelitian Hesti Sadtyadi dari data penelitian, menunjukan bahwa guru memiliki peluang terjadinya tekanan kerja yang dapat berasal dari siswa, maupun tugas tambahan yang dibebankannya. Selain tu tekanan kerja dalam hal ini juga dapat disebabkan oleh adanya sarana prasarana pendukung dalam proses pelaksanaan tugas guru yang tidak terdukung dengan baik. Ketiga indikator tersebut dapat menyebabkan terjadinya tekanan kerja dalam pelaksanaan kerja tersebut.

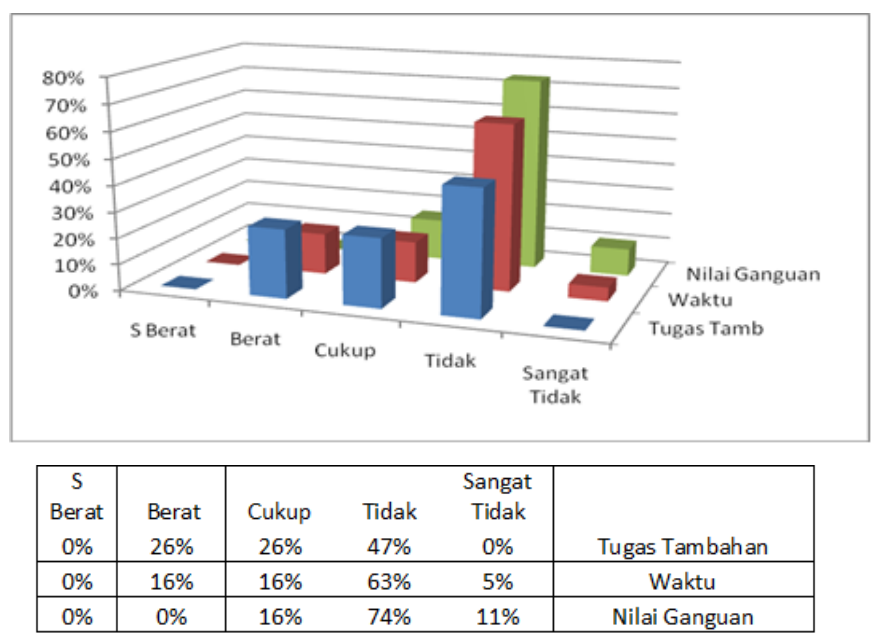

Dapat dijelaskan bahwa tugas tambahan, dengan prosentase berat sebesar $26 \%$, sedangkan cukup berat sebesar $26 \%$ dan $47 \%$ memberikan penialian tidak berat. Berdasarkan penggunaan waktu yang ada $16 \%$ berat, dan $16 \%$ cukup berat dan $63 \%$ tidak berat dan $5 \%$ menyatakan sangat tidak berat. Jika dilihat dari nilai gangguan menunjukan $16 \%$ cukup terganggu, $74 \%$ tidak terganggu, dan $11 \%$ sama sekali tidak terganggu. Jika komponen data disatukan maka 
tergambarkan setidaknya dari tiga komponen tersebut menggambarkan bahwa setidaknya $16 \%$ lebih guru merasa endapatkan tekanan kerja yang berasal dari siswa, sarana prasarana dan penggunaan waktu dalam pelaksanaan tugasnya.

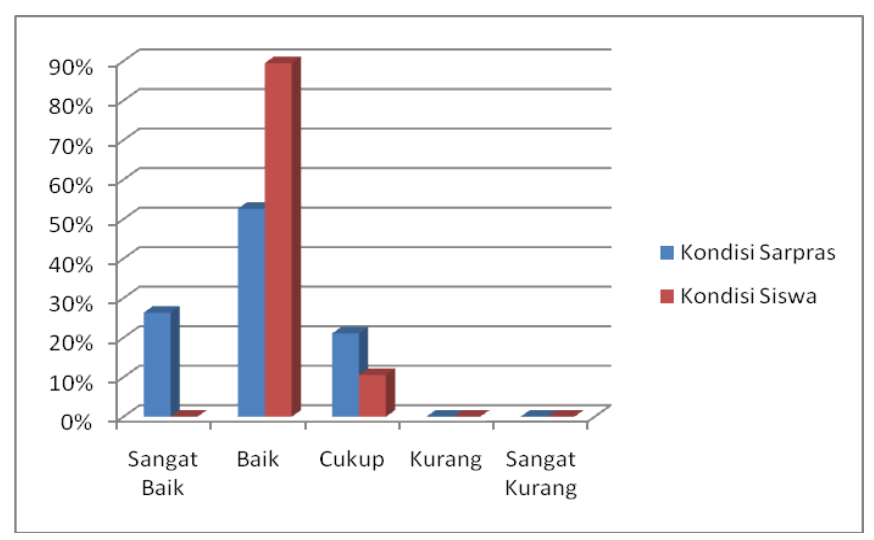

\begin{tabular}{|c|c|cc|cc|}
\hline $\begin{array}{c}\text { Sangat } \\
\text { Baik }\end{array}$ & Baik & Cukup & Kurang & $\begin{array}{c}\text { Sangat } \\
\text { Kurang }\end{array}$ \\
\hline $26 \%$ & $53 \%$ & $21 \%$ & $0 \%$ & $0 \%$ & Kondisi Sarpras \\
\hline $0 \%$ & $89 \%$ & $11 \%$ & $0 \%$ & $0 \%$ & Kondisi Siswa \\
\hline
\end{tabular}

Kondisi siswa yang dimiliki guru pendidikan agama Buddha secara umum memiliki kondisi cukup baik $11 \%$ dan $89 \%$ baik. Artinya kondisi siswa pendidikan agama Buddha relatif tidak menjengkelkan atau guru cukup mampu mengatasi kesulitan kelas, dalam berhubungan dengan siswanya. Gambaran ini dapat pula memberikan arti bahwa terdapat potensi yang dpat ditingkatkan menjadi lebih baik, atau terdapat potensi yang dapat di maksimalkan. Dilihat dari sisi yang lain, menunjukan terdapatnya potensi yang dapat menyebabkan potensi guru pendidikan agama Buddha terganggu dalam menjalankan tugas karena adanya karakter siswa, yang kadang kurang mendukung proses belajar, walaupun prosentase yang menyebabkan relatif kecil, tetapi potensi masalah tetap da, dan dapat menyebabkan kurangnya percaya diri dan stres kerja bagi guru.

Dalam proses pelaksanaan tugas guru pendidikan agama Buddha, harus didukung pula dengan sarana prasarana yang memadai. Berdasarkan data berkaitan dengan sarana prasarana, yang meliputi buku dan penunjang, juga ruang belajar pendidikan agama Buddha, yang menunjukkan bahwa $26 \%$ telah tercukupi dengan sangat baik, 53\% dengan ketercukupan yang baik, dan 21\%, dalam kategori cukup. Indikator dalam hal ketersediaan sarana prasarana dalam hal ruang, maa dapat memberikan petunjuk, bahwa $21 \%$ dari pelaksanaan tugas guru pendidikan agama Buddha dalam mengajar, mendapat ruang untuk belajar walaupun bukan ruang belajar atau ruang kelas. Hal ini disebabkan karena ketersediaan ruang yang terbatas, selain jumlah siswa pendidikan agama Buddha, yang secara umum kurang dari 20 siswa tiap angkatan atau kelasnya. Kondisi ini harusnya menjadikan perhatian guna meningkatkan potensi dan kinerja guru tersebut. Dampak dari keterbatasan ini adalah proses belajar yang kurang sempurna, yang dpat disebabkan karena keterlaksanaan tugas masih dalam standar yang kurang, dan dapat menjadi tekanan kerja bagi guru pendidikan agama Buddha.

Sarana penunjang yang lain seperti buku, juga dapat dijelaskan bahwa keberadaan buku pendidikan agama Buddha, yang masih sangat jarang, dan terbatas. Keterbatasan disebabkan karena tidak adanya pasar yang memasarkan berbagai jenis produk buku pendidikan agama Buddha, karena peluang pengguna yang minim, dan ketergantungan buku dari bantuan. Sehingga guru dan siswa pendidikan agama Buddha dalam proses belajar tergantung dari satu jenis buku, yang diperoleh dari bantuan atas usaha guru. Kondisi ini dapat pula menjadi bagian kesibukan guru dalam usaha memperoleh buku buku 
penunjang, yang dapat pula menjadi sebab tekanan kerja, stres kerja, yang berakibat pada percaya diri guru pendidikan agama Buddha.

Memperlihatkan data dan gambar terkait dengan kodisi siswa dalam proses pembelajaran, yang dapat disampaikan bahwa secara umum tidak memiliki masalah, sekalipun demikian terdapat potensi walaupun relatif kecil, seperti pada ditunjukkan dari data dalam jawaban atas pernyataan instrumen yang dapat menggambarkan bahwa tidak terdapat permasalahan dengan siswa dalam proses pembelajaraan. Terdapat $5 \%$ jawaban responden yang memberikan respon jengkel dan, jika anak didik membuat respon yang menjengkelkan, 95\% jawaban reponden yang memberikan respon yang baik pada guru. Terdapat pula jwaban responden yang sama sekali tidak menunjukan ualah anak yang membuat guiru marah yakni $100 \%$. Terdapat $11 \%$ yang menahan diri jika terdapat perilaku siswa yang tidak menyenangkan, serta $89 \%$ jawaban responden guru dapat menahan diri tidak marah ketika terdapat perilaku siswa yang tidak menyanangkan. Terdapat $100 \%$ jawaban reponden menunjukan bahwa siswa mempunyai kemampuan akdemik yang unggul. Terdapat pula jawaban responden mengatakan siswa memperhatikan penuh pelajaran yakni dengan nilai $100 \%$. dari pernyataan tersebut menandakan masih terdapat potensi yang harus diperhatikan, karena dari dua pernyataan diantara perasaan jengkel dan perasaan marah masih dapat menjadi bagian dari stres kerja dan berpotensi berpengaruh terhadap kinerja selain rasa percaya diri yang masing-masing menunjukan $5 \%$ dan $11 \%$.

Tabel. 5

Respon terhadap siswa

\begin{tabular}{|l|ll|}
\hline \multicolumn{1}{|c|}{ Pernyataan instrumen } & Ya & Tidak \\
\hline Anak didik sering membuat ulah yang menjengkelkan & $5 \%$ & $95 \%$ \\
\hline Ulah anak didik membuat saya marah & $0 \%$ & $100 \%$ \\
Menahan diri, tidak marah jika perilaku siswa tidak & $89 \%$ & $11 \%$ \\
menyenangkan. & & \\
\hline Siswa tidak memiliki kemampuan akademik & $0 \%$ & $100 \%$ \\
Siswa kurang memperhatikan pelajaran & $0 \%$ & $100 \%$ \\
\hline
\end{tabular}

Tabel. 6

Konflik dengan sejawat

\begin{tabular}{|l|l|ll|}
\hline No & \multicolumn{1}{|c|}{ Pernyataan } & Ya & Tidak \\
\hline 1 & Sering beda pendapat dengan sejawat & $11 \%$ & $89 \%$ \\
2 & Dibantu sejawat & $74 \%$ & $26 \%$ \\
3 & Mendapat pertolongan dari sejawat & $47 \%$ & $53 \%$ \\
\hline 4 & Kawan sejawat acuh & $5 \%$ & $95 \%$ \\
\hline 5 & Kesulitan berkomunikasi & $16 \%$ & $84 \%$ \\
\hline 6 & Diperolok oleh sejawat & $5 \%$ & $95 \%$ \\
7 & Tidak disuka & $5 \%$ & $95 \%$ \\
\hline
\end{tabular}

Dalam data konflik dengan sejawat tampak bahwa guru sedikit memiliki konflik dengan sejawatnya. $11 \%$ guru yang sering mengalami beda pendapat dengan sejawatnya dan 89\% tidak mengalami beda pendapat dengan teman sejawat. Sebanyak $74 \%$ guru dalam hal tugas sering dibantu sejawat, ada pula $26 \%$ guru tidak dibantu sejawatnya dalam hal tugasnya, sedangkan dalam hal tugas lainnya 53\% tidak dibantu oleh sejawatnya. Kesulitan berkomunikasi dengan sejawat dialami guru sebanyak $16 \%$ dan merasa tidak suka sebanyak 5\%. Gambaran ini menandakan, terdapatnya potensi adanya konflik dengan sejawat, walaupun relatif kecil. Kondisi yang signifikan didalam konflik ini merupakan arti bahwa terdapat stres kerja, dan atau rasa percaya diri, yang dapat mempengaruhi kinerja atau prestasi kerja guru tersebut.

Tabel.7

Konflik dengan siswa

\begin{tabular}{|l|l|c|c|}
\hline No & \multicolumn{1}{|c|}{ Pernyataan } & Ya & Tidak \\
\hline 1 & $\begin{array}{l}\text { Siswa sering } \\
\text { menjengkelkan }\end{array}$ & $5 \%$ & $95 \%$ \\
\hline 2 & $\begin{array}{l}\text { Kesulitan mengendalikan } \\
\text { siswa }\end{array}$ & $0 \%$ & $100 \%$ \\
\hline
\end{tabular}




\begin{tabular}{|l|l|l|l|}
\hline 3 & $\begin{array}{l}\text { Seringnya ditemui siswa } \\
\text { menangis }\end{array}$ & $32 \%$ & $68 \%$ \\
\hline 4 & Kelas sering gaduh & $26 \%$ & $74 \%$ \\
\hline 5 & $\begin{array}{l}\text { Kemudahan siswa terima } \\
\text { materi }\end{array}$ & $89 \%$ & $11 \%$ \\
\hline 6 & $\begin{array}{l}\text { Siswa tidak mengerjakan } \\
\text { tugas }\end{array}$ & $0 \%$ & $100 \%$ \\
\hline 7 & $\begin{array}{l}\text { Mata pelajaran dianggap } \\
\text { tidak penting }\end{array}$ & $0 \%$ & $100 \%$ \\
\hline 8 & Siswa bermain sendiri & $37 \%$ & $63 \%$ \\
\hline
\end{tabular}

Terdapat potensi permasalahan yang dapat menimbulkan stres kerja ataupun rasa tidak percaya diri, yang ditimbulkan dari pekerjaanya khususnya dari siswa, dapat dijelaskan dari data yang menunjukan 95\% tidak menjengkelkan, tetapi ada siswa yang sering menjengkelkan sebanyak 5\%. Dalam hal pengendalian, guru masih bisa mengkondisikan siswa dalam kelas agar kondusif. Terdapat siswa sering gaduh $26 \%$. Adapun sering ditemukan keadaan siswa yang sering menangis $32 \%$. Siswa yang membuat gaduh kelas sebesar 26\%. Siswa yang tidak mengerjakan tugas di dalam kelas tidak ditemukan guru dalam pembelajaran, hal ini menandakan siswa tertib dan rajin. Dalam hal mata pelajaran semua mata pelajaran oleh siswa dianggap penting. Terdapat pula siswa bermain sendiri $37 \%$, yang menandakan bahwa kurangnya perhatian siswa dalam belajar di kelas. Gambaran data ini juga manandakan adanya potensi masalah dengan siswa sehingga masih membuat stress guru dalam bekerja.

\section{C.Faktor, Indikator Percaya Diri dan Besarnya Pengaruh Percaya Diri}

\section{terhadap Prestasi Kerja Guru Pendidikan} Agama Buddha

Berdasarkan analisis yang dilakukan, melalui kajian teoritis, juga dilakukan telaah dengan menggunakan FGD, menunjukkan bahwa percaya diri memiliki dua komponen utama yang berpengaruh, yakni dari lingkungan kelas, yang terdiri dari suasana kelas yang terbagi dalm indikator sarana pendukung belajar, seperti ruang kelas dan lainnya, buku dan penunjang lainnya, jumlah siswa, lokasi dan jumlah kelas yang menjadi tempat tugas.

Faktor lingkungan yang kedua adalah lokasi tugas tambahan yang sesuai, tugas-tugas tambahan lainnya, baik sebagai administrasi atau bidang tugas yang lain, sarana pendukung tugas tambahan, dan tekanan kerja dari tugas tambahan yang ada. Masing-masing sub komponen terdiri dari empat indikator yang menyusunnya. Kedua sub komponen yaitu lingkungan kelas, dan lingkungan tugas tambahan, merupakan sub komponen yang menyusun percaya diri guru pendidikan agama Buddha.

Besarnya pengaruh langsung percaya diri terhadap prestasi kerja atau kinerja guru pendidikan agama Buddha dapat ditunjukkan melalui analisis Regresi linear yang menghasilkan besarnya pengaruh langsung sebesar 0,318

\section{KESIMPULAN}

Berdasarkan analisis, yang dilakukan melalui dengan FGD maupun analisis EFA, dapat disimpulkan :

1. Faktor yang mempengaruhi percaya diri guru pendidikan agama Buddha dalam pelaksanaan tugasnya adalah faktor lingkungan suasana 
kelas dan faktor lingkungan dari tugas tambhan yang dimiliki guru tersebut.

2. Indikator yang mempengaruhi Lingkungan kelas, terdiri dari suasana kelas yang terbagi dalam indikator sarana pendukung belajar, seperti ruang kelas dan lainnya, buku dan penunjang lainnya, jumlah siswa, lokasi dan jumlah kelas yang menjadi tempat tugas. Sedangkan faktor lingkungan yang kedua adalah lokasi tugas, tambahan yang sesuai, tugas-tugas tambahan lainnya, baik sebagai administrasi atau bidang tugas yang lain, sarana pendukung tugas tambahan, dan tekanan kerja dari tugas tambahan yang ada.

3. Besarnya pengaruh percaya diri terhadap kinerja pendidikan agama Buddha sebesar 0,318 yang menunjukkan bahwa prestasi kerja dapat dipengaruhi secara langsung melalui rasa percaya diri sebesar 0,318 . Jika rasa percaya diri mampu ditingkatkan dalam satusatuan, dengan asumsi variabel lain tetap, maka prestasi kerja dapat ditingkatkan sebesar 0,318 .

\section{Saran}

Berdasarkan analisis dan simpulan dapat disarankan sebagai berikut :

1. Perlunya memperhatikan sarana prasaraana pendukung pendidikan agama Buddha, dengan memberikan kelengkapan belajar yang sesuai dengan kaidah pelaksanaan tugas belajar.

2. Pelaksanaan tugas tambahan sebaiknya adalah tugas yang sesuai dengan kompetensi dan menjadi bagian pendukung dalam meningkatkan kemampuan guru sesuai dengan tugas pokok dan fungsinya.
3. Perlunya memberikan tenaga pengadministrasi secara formal di pendidikan sekolah dasar.

\section{DAFTAR PUSTAKA}

Borg,W.R.,\& Gall,M.D. (1983). Education research: an introduction.New York: Longman inc.

Eisengart, S.P., et al. (2006). Factor Structure of Coping: Two Studies of Mother With High Levels of Life Stress, Psychological Assessment, 2006, Vol. 18, No. 3, 278-288.

Evans, J.R., \& Lindsay, W.M., (2002). The Management and Control Of Quality. (fifth edition). South western, USA

Ghufron M Nur, (2014). Teori-Teori Psikologi. Jogjakarta. Ar-Ruzz Media

Jones, j., et al., (2006). Developing Effective Teacher Performance, Paul Chapman, A Sage Publication, California.

Sugiyono. (2015). Statistika untuk Penelitian. Bandung: Alfabeta.

Sugiyono,(2016). Metode Penelitian Dan Pengembangan. Bandung:

Cv.Alfabeta

Depdiknas. (2005) Undang-Undang RI. No 14 tahun 2005, tentang Guru dan Dosen

(2008). Peraturan Pemerintah

Nomor 74 Tahun 2008, tentang Guru

(2012). Permendiknas nomor 35 Tahun 2012, tentang Petunjuk Teknis Pelaksanaan Jabatan Fungsional Guru dan Angka Kreditnya 